\title{
Social Network Sites as ESL/EFL Learning and Teaching Tools: A Critical Review
}

\author{
Sulaiman Alnujaidi \\ College of Languages and Translation, Al-Imam Muhammad Ibn Saud University, Riyadh, Saudi Arabia \\ E-mail: sulaiman_alnujaidi@yahoo.com
}

Received: 17-10-2016

Accepted: 29-12-2016

Advance Access Published: March 2017

Published: 01-05-2017

doi:10.7575/aiac.ijalel.v.6n.3p.34

URL: http://dx.doi.org/10.7575/aiac.ijalel.v.6n.3p.34

\begin{abstract}
This study analyzed the educational and instructional implications of Social Network Sites (SNS) in the ESL/EFL teaching and learning context. SNS's definition, types, classifications, features, positive and negative aspects, their educational implications as well as their limitations and challenges in the ESL/EFL classroom settings are identified and discussed in order to better utilize and integrate their innovative aspects into the language teaching and learning practices.

Keywords: Social Networking Sites (SNS), English as a Second Language (ESL), English as a Foreign Language (EFL), Teaching English as a Second Language (TESL), Teaching English as a Foreign Language (TEFL), Second Language (L2)

\section{Introduction}

As this ear is characterized by exponentially growing technological advances, millions of people use Social Network Sites (SNS), such as Facebook, Twitter, YouTube, Instagram, and MySpace, to connect with each other based on shared interests, political views, or activities (Clarkson, 2013). Technology could change what, how, and where people learn (Warschauer, 2006). However, technology should not be regarded as "a magic bullet to solve educational problems, but rather as a powerful tool that can have both positive and negative impact, and that must be carefully exploited" (Warschauer, 2009, p. xx). In the educational settings, students are already using SNS; and therefore, educators, instructors, and teachers are faced with the choice whether to work with or against them. (Pegrum, 2009).
\end{abstract}

\subsection{Statement of the Problem}

The present ESL/EFL teachers are confronted with many technological advances that present opportunities as well as challenges to their profession. ESL/EFL students of today are technologically savvy. "Even the most dynamic EFL teacher is going to be operating at a loss when it comes to YouTube and Twitter being secretly watched and talked about beneath desks and behind folded books" (Morris, 2011, p. 1).

Some of the most famous SNS; namely Facebook, YouTube, Twitter, and Instagram were discussed below. Their potentials and drawbacks were also be presented along with educational implications especially as they pertain to ESL/EFL teaching and learning.

1.2 Purpose of the Study

As SNS can influence ESL/EFL learning, it is critically important to carefully study and analyze their educational implications and challenges. Given the importance of this topic, this study addressed the following research questions:

1. What are the most popular SNS?

2. What are the positive and negative aspects of SNS?

3. How can SNS be implemented as ESL/EFL tools?

1.3 Significance of the Study

The results of this study can provide valuable insights into how SNN should be incorporated into language instruction and what ESL/EFL teachers need to know to implement SNS into their teaching practices.

\section{Literature Review}

\subsection{Definition of Social Network Sites}

As information and communication technological tools have accelerating change, defining SNS has become a challenge for researchers. According to Boyd and Ellison (2007), SNS are "web-based services that allow individuals to (1) construct a public or semi-public profile within a bounded system, (2) articulate a list of other users with whom they share a connection, and (3) view and traverse their list of connections and those made by others within the system" (p. 211). Kaplan and Haenlein (2010) viewed SNS as "a group of Internet- based applications that build on the ideological and technological foundations of Web 2.0 and that allow the creation and exchange of user-generated content" (p. 61). Kachniewska (2015) introduced a similar conceptualization and defined SNS as "a group of Internet-based applications 
that build on the ideological and technological foundations of Web 2.0 and depend on mobile and web-based technologies to create highly interactive platforms through which individuals and communities share, co-create, discuss, and modify user-generated content" (p. 18). Carr and Hayes (2015) expanded their definition and argued that SNS are "internet-based channels that allow users to opportunistically interact and selectively self-present, either in real-time or asynchronously, with both broad and narrow audiences who derive value from user-generated content and the perception of interaction with others" (p. 50). Drawing on previous definitions, Kamel (2016) described SNS as "computer-mediated tools and applications that allow people to create, share or exchange information, ideas, pictures and videos in virtual communities and networks in real time irrespective of time or distance barriers" (p.1229). The challenge to conceptualize a clear-cut definition of SNS can be attributed to two reasons. Firstly, the speed at which technology is emerging and evolving; and secondly, the similarities between SNS and other forms of technologies in terms of collaboration and communication (Obar and Wildman, 2015).

Carr and Hayes (2015) differentiated between Social Media and Social Network Sites. They argued that even "though SNS are typically social media tools, not all social media are inherently social network sites". (p. 51). Boyd and Ellison (2007) also made a clear distinction between Social Network Sites and Social Networking Sites. They claimed that "Networking emphasizes relationship initiation, often between strangers; while on many SNS, participants are not necessarily networking or looking to meet new people; instead, they are primarily communicating with people who are already a part of their extended social network" (p. 211).

A close analysis of literature on this topic revealed that the terms social network sites, social network services, social media networks, online social networks, and Web 2.0 have been used interchangeably. For the scope of this study, the term "social network sites" was used to refer to any web-based and/or mobile technology which takes on many different platforms including weblogs, social blogs, microblogs, wikis, podcasts, videocasts, picture and video sharing, and social bookmarking.

\subsection{The Most Popular Social Network Sites}

Table 1 lists The World's Most Popular Social Network Sites (2016) according to eBizMBA Rank as updated on October, 1, 2016. eBizMBA Rank is a constantly updated average of each website's Alexa Global Traffic Rank and U.S. Traffic Rank from both Compete and Quantcast.

Table 1. The Worl's Most Popular Social Network Sites (eBizMBA, 2016)

\begin{tabular}{lcccccc}
\hline \multicolumn{1}{c}{ SNS } & $\begin{array}{c}\text { Monthly } \\
\text { Visitors }\end{array}$ & $\begin{array}{c}\text { eBizMBA } \\
\text { Rank }\end{array}$ & $\begin{array}{c}\text { Compete } \\
\text { Rank }\end{array}$ & $\begin{array}{c}\text { Quantcast } \\
\text { Rank }\end{array}$ & $\begin{array}{c}\text { Alexa } \\
\text { Rank }\end{array}$ & Total Rank \\
\hline Facebook & 1.100 .000 .000 & 3 & 3 & 3 & 2 & 1 \\
\hline YouTube & 1.000 .000 .000 & 3 & 4 & 2 & 3 & 2 \\
\hline Twitter & 310.000 .000 & 12 & 21 & 8 & 8 & 3 \\
\hline LinkedIn & 255.000 .000 & 18 & 25 & 19 & 9 & 4 \\
\hline Pinterest & 250.000 .000 & 22 & 27 & 13 & 26 & 5 \\
\hline Google Plus+ & 120.000 .000 & 30 & 32 & 28 & NA & 6 \\
\hline Tumblr & 110.000 .000 & 34 & 55 & 13 & 34 & 7 \\
\hline Instagram & 100.000 .000 & 77 & 49 & 145 & 36 & 8 \\
\hline Reddit & 85.000 .000 & 85 & 81 & 146 & 30 & 9 \\
\hline VK & 80.000 .000 & 97 & 150 & 120 & 21 & 10 \\
\hline Flickr & 56.000 .000 & 123 & 138 & 139 & 91 & 11 \\
\hline Vine & 42.000 .000 & 581 & 237 & 335 & 1172 & 12 \\
\hline Meetup & 40.000 .000 & 596 & 791 & 701 & 296 & 13 \\
\hline Ask.fm & 37.000 .000 & 779 & 2046 & 113 & 179 & 14 \\
\hline Classmates & 15.000 .000 & 1487 & 153 & 285 & 4022 & 15 \\
\hline
\end{tabular}

\subsection{Classifications of Social Network Sites}

As new SNS are likely to emerge almost every day with more different and advanced features, there is no systematic way to categorize types of SNS (Kaplan and Haenlein, 2010). Alternatively, a systematic classification scheme based on a set of theories in the field of media research (social presence and media richness) and social processes (selfpresentation and self-discourse) was proposed by Kaplan and Haenlein (2010). The first dimension is a combination of social presence and media richness. Social presence refers to the acoustic, visual and physical contact between two communicators, while media richness is the amount of information that they (media) allow to be transmitted in a given time interval. The second dimension is a combination of the propensity to develop interactions with other people in order to control their impression (self-presentation) and the conscious or unconscious revelation of personal information 
that is consistent with the image one would like to give (self-disclosure). The four theories were used to divide SNS into six categories as shown in Table 2 .

Table 2. Classification of Social Media (Kaplan and Haenlein, 2010)

\begin{tabular}{|c|c|c|c|c|}
\hline \multirow{4}{*}{$\begin{array}{l}\text { Self- } \\
\text { presentation/Self- } \\
\text { disclosure }\end{array}$} & & \multicolumn{3}{|c|}{ Social presence/Media richness } \\
\hline & & Low & Medium & High \\
\hline & High & Blogs & $\begin{array}{l}\text { Social networking sites } \\
\text { (e.g., Facebook) }\end{array}$ & $\begin{array}{l}\text { Virtual social } \\
\text { worlds } \\
\text { (e.g., Second Life) }\end{array}$ \\
\hline & Low & $\begin{array}{l}\text { Collaborative projects } \\
\text { (e.g., Wikipedia) }\end{array}$ & $\begin{array}{l}\text { Current communities } \\
\text { (e.g., YouTube) }\end{array}$ & $\begin{array}{l}\text { Virtual game worlds } \\
\text { (e.g., World of } \\
\text { Warcraft) }\end{array}$ \\
\hline
\end{tabular}

Thelwall (2009) proposed another classification of SNS based on a distinction between the purposes for which SNS tools are utilized as follows: (1) socializing SNS which are designed for recreational social communication between members such as Facebook, and MySpace ; (2) networking SNS which are designed for non-social interpersonal communication such as LinkedIn; (3) navigation SNS which are designed to help users find a particular type of information or resource such as YouTube, Flickr, and Digg. Similarly, Manca and Ranieri (2015) classified SNS, according to their purposes, into three categories: (1) educational SNS which offer communication, collaboration, and coaching tools to schools and teachers, such as Edmodo and Ning; (2) professional/research SNS which are used for sharing research, such as LinkedIn, ResearchGate, and Academia; and (3) social-relational SNS which are used for social interaction, such as Facebook, Twitter, and Google Plus.

Drawing on the previous findings, Howard and Parks (2012) noted that SNS consist of three parts: “ (a) the information infrastructure and tools used to produce and distribute content; (b) the content that takes the digital form of personal messages, news, ideas, and cultural products; and (c) the people, organizations, and industries that produce and consume digital content" (p. 362). SNS has also been classified according to its support to multiple modes of communication: (1) one to many and one to one; (2) synchronous and asynchronous; (3) textual and media based; and (4) public or private (Ellison and Boyd, 2013). Other researchers have also identified common features of SNS. Duffy (2011) argued that a user can (a) create a profile, (b) find peers online, (c) publicly erect or confirm peer connections, (d) collaborate to share content, and (e) form online communities. These assertions are similar to what was reported by Obar and Wildman (2015) who synthesized four commonalities among SNS as follows:

1. SNS are Web 2.0 Internet-based applications.

2. User-generated content is the lifeblood of social media.

3. Individuals and groups create user-specific profiles for a site or application designed and maintained by a social media service.

4. SNS facilitate the development of social networks online by connecting a profile with those of other individuals and/or groups.

\section{Discussion}

Warschauer (2009) noted that technology should not be regarded as "a magic bullet to solve educational problems, but rather as a powerful tool that can have both positive and negative impact, and that must be carefully exploited" (p. xx). The use of technology, in a broad sense, allows students to develop several different lifelong learning skills and create rich and deeper learning environment that is social, active, contextual, engaging, and student-owned (Carmean and Haefner, 2002). New technologies could change what, how, and where people learn (Warschauer, 2006). SNS have its own educational implications and challenges when it comes to the teaching and learning context, and English language instruction in particular.

\subsection{Positive and Negative Aspects of Social Network Sites}

The most distinctive feature of SNS is the fact that they target diverse audiences based on shared linguistic, racial, sexual, religious, or nationality-based identities (Boyd and Ellison, 2007). Significant benefits associated with the use of SNS includes: delivering educational outcomes; facilitating supportive relationships; identity formation; and, promoting a sense of belonging and self-esteem (Collin, Rahilly, Richardson, and Third, 2011). Most importantly, SNS have been reported to shift the role of educators from the gatekeeper to a facilitator, provide learners with educational information in a non-linear form, support social interaction and educational communication, provide a platform for expressing ideas, break the time, place, and environmental constraints, support collaborative learning, and support reflective learning (Chen, Diao, and Zhang, 2011). These findings are similar to what was reported by a focus group study which revealed that SNS could be used to spread announcements, provide easy communications, encourage discussion, motivate people to share things, provide rich content and resources, enable restudying, provide self-evaluation and easy connection (Vural, 2015). Through enabling dialogue and turning passive, knowledge-receiving students into active, knowledge- 
making students, SNS are starting to break down the barriers between inside and outside the classroom and bridge that gap between traditionally-bounded and technologically-unbounded learning environments (Robbins-Bell, 2008).

Hung and Yuen (2010) investigated the use of SNS as a supplementary tool to face-to-face courses and concluded that students developed strong feelings of social connectedness and expressed favorable feelings regarding their learning experiences (2010). Similar assertions were reported by Blattner and Fiori (2009) who argued that SNS contribute in fostering positive relationships among students and providing many opportunities for them to interact with peers, instructors and native speakers. Additionally, a growing number of university professors use SNS to connect with colleagues around the country as well as in the classroom to retain student engagement and encourage dialogue (The Faculty Focus, 2009). SNS products and applications are rapidly evolving while universities are exploring new ways to implement them and encourage faculty members to utilize them to support learning. Therefore, higher education institutions should understand students' SNS practices as long as SNS are "fundamentally changing the social fabric of the university" (Ellison, 2008: 19).

Although higher education scholars are using SNS for personal, teaching, and professional purposes, their use is still limited and restricted (Manca and Ranieri, 2016). Drawing on their drawbacks, SNS were reported to waste time, minimize socializing, encourage plagiarism, violate privacy, spread harmful and unreliable information, create fake characters, and cause distraction, disturbance, gossiping, and addiction (Vural, 2015). Therefore, education institutions should invest time, money, and effort in preparing their faculty members to use and integrate SNS into their teaching practice as well as address and minimize the negative aspects that are usually associated with using SNS in the teaching and learning context.

\subsection{SNS as ESL Learning/Teaching Tools}

Current views on L2 teaching emphasize the vital role of communicative and cultural competence in L2 learning. Canale and Swain (1980) listed four components of communicative competence: grammatical competence (words and rules), sociolinguistic competence (appropriateness), discourse competence (cohesion and coherence), and strategic competence (appropriate use of communication strategies). Cultural competence is the ability to interact effectively with people across different cultures. It has four components: an awareness of one's own cultural worldview, positive attitude towards cultural differences, knowledge of different cultural practices and worldviews, cross-cultural communication skills (Fenner, 2008). SNS have been proven to enhance both communicative and cultural competence (Borau, Ullrich, Feng, and Shen, 2009).

Current second language learning/acquisition research on the use of SNS technologies, such as Facebook, Twitter, YouTube, Blogs, Wikis, etc., have been described to have "a paradigm shift as it is moving from a cognitive orientation to a social orientation, from classroom contexts to naturalistic settings, from an acquisition metaphor to a participation metaphor, and from L2 learning to L2 use" (Wang \& Vasquez, 2012, p. 413); therefore, the application of SNS technologies in many L2 learning contexts has transformed pedagogy, curriculum design, language learning conception, and even the research in this field (Wang \& Vasquez, 2012). SNS have created new opportunities for language learners and teachers to interact in authentic ways that were previously difficult to achieve, have encouraged students to experiment with language in a constructive web-based learning environment, and have increased students' motivation through providing them with access to a variety of tasks and resources in multimedia formats (Chartrand, 2012). Pauwels (2011) stressed the impact of technology-mediated interaction on the acquisition of the four skills in foreign language learning (speaking, listening, reading, and writing) and argued that the new generation of language learners would prefer technology-mediated interaction modes of communication for both learning and social purposes. Tudini (2015) also emphasized that communication technologies, such as SNS, could provide foreign language students with virtual immersion and learning opportunities as well as higher levels of real-time interaction and appropriately timed, individualized environments. Manuel and Schunke (2016) stated that teachers need to teach students about social media and not just teach with social media.

SNS integration into ESL teaching can increase students' knowledge and motivation as well as build their confidence in learning. Therefore, both teachers and students should have relevant technical skills to maximize on SNS potentials (Yunus, Salehi, and Chenzi, 2012). SNS has also been proven to facilitate dynamic communication inside and outside classrooms, create a sense of community and belonging, provide authentic exposure to English, and stimulate motivation to learn English in an authentic fashion (Kikuchi and Otsuka, 2008). Not only could SNS assist in the acquisition of lower thinking skills (e.g., basic vocabulary), but it could also offer language learners opportunities to acquire higher proficiency skills with more complex structures that involve conceptual learning (Alm, 2006). Alm's assertions are similar to the findings of Ho-Abdullah, Hashim, Jaludin, and Ismail (2011) who examined how webbased social networking can be used to provide ESL students with the opportunity to use English and to reflect on and improve ESL teachers' practices. They found that web-based social networking encouraged students' English language use in informal settings. Some of the most famous SNS tools are discussed below along with their potentials as well as limitations.

\subsection{Facebook as an ESL/EFL Tool}

Launched in 2004 as an online social networking service, Facebook has now become the first mostly visited SNS worldwide (eBizMBA, 2016), and has changed the way people communicate and access information (Saykili and Kumtepe, 2016). Facebook-integrated instruction can significantly enhance students' interest and motivation (Ru-Chu 2011). Facebook groups can also be effective in teaching ESL writing. ESL/EFL students can learn new vocabularies 
from reading group members' comments, and the spell-check feature can help reduce spelling errors (Melor \& Salehi 2012). These findings are similar to what was reported by Camus, Hurt, Larson, and Prevost (2016) who compared the effects of a Facebook-based and LMS-based online discussion forum on students' participation, achievement of learning goals, and overall course performance. They found Facebook better at fostering student participation and encouraging peer-to-peer dialogue. Mahmud and Ching (2012) provided an account of how Facebook was incorporated as a pedagogical means in the ESL settings and concluded that the utilization of Facebook had generally enhanced students' L2 skills such as reading and writing, expanded their social circles, improved their communication skills, and minimized their apprehension when learning and using the language among their peers. Similarity, Kho \& Chuah (2012) used Facebook as a tool to facilitate students' discussion activity and recommended that ESL teachers incorporate the use of Facebook in their teaching activities in order to make the lessons more fun and interactive. These assertions are similar to what was reported by Hanafi, Alberth, Wiramihardja, Siam, and Badara (2013) who identified some advantages for using Facebook as an ESL/EFL tool as follows:

1. It enables students to use L2 for real life purposes.

2. It exposes students to authentic materials.

3. It allows students to communicate with native speakers.

4. It provides students with access to unlimited resources online (news, audios, videos, etc.).

5. It allows students to understand L2 culture.

Despite its numerous educational advantages, one of the drawbacks that is often discussed when using Facebook in the teaching and learning context is its privacy violation. Students get more confident in their English writing skills and become more open to talk about their private lives online, which may lead to identify theft. Therefore, teachers and students need to discuss some guidelines and agree on some rules before they start using it (Chartrand, 2012).

\subsection{YouTube as an ESL/EFL Tool}

Launched in 2005 as a video-sharing website, YouTube has now become the second mostly visited SNS worldwide (eBizMBA, 2016), and has allowed millions of people to easily upload, download, view, and share video clips through several different platforms. YouTube is a free innovative online resource that allows instructors to create studentrelevant content and learning, engaging environment (Burke, Snyder, and Rager, 2009). YouTube generated tremendous interest and motivation in ESL/EFL students with its video streaming capabilities (Hamilton, 2010). YouTube has a number of ESL-related videos posted by teachers and students that can be incorporated into the ESL classroom to promote discussions among students (Chartrand, 2012). Using YouTube both inside and outside the classroom can enhance conversation, listening, and pronunciation skills, improve vocabulary development, stimulate learner autonomy, promote L2 cultural competence, and increase exposure to World Englishes (Watkins and Wilkins, 2011). These findings are similar to what was reported by Burke, Snyder, and Rager (2009) who identified some advantages for using YouTube as an instructional tool as follows:

1. It provides a wealth of authentic and reliable video materials.

2. It offers real-life examples and visual demonstrations of the topics and concepts covered in class.

3. It provides lesson/lecture launchers to promote discussion and critical thinking.

Albeit YouTube has several remarkable features, it also has some challenges when utilized in the teaching and learning context. Instructors should make sure that the video clips are appropriate, accurate, and credible. Instructors should guarantee that the video clips selected for their students do not discriminate against age, gender, race, disability, and religious orientation. Some video clips may require guidance from the teachers. Video clips with provocative language and/or nudity should be avoided. Also, the video clips should accurately address the skills that are targeted to be learned by students. Instructors should only use video clips from reliable sources as well as consider copyright restrictions (Burke, Snyder, and Rager, 2009).

\subsection{Twitter as an ESL/EFL Tool}

Launched in 2006 as an online social networking service, Twitter has now become the third mostly visited SNS worldwide (eBizMBA, 2016), and has fascinated millions of users with its short format and unique way of communicating (Chartrand, 2012). Many ESL/EFL writing, listening, vocabulary, and research activities could be initiated and incorporated through Twitter because Twitter could improve students' written communication skills as well as their analytical, collaborative, and social networking skills (Mork, 2009). Twitter could also create a classroom community, promote collaborative writing, foster editing skills, develop literacy skills, provide reader response, offer students opportunities to discuss issues in formal and informal settings, provide collaboration across schools and countries, enhance group-project management, assess opinion and examine consensus, foster interaction about a given topic, and enhance metacognition (Grosseck and Holotescu, 2008). After incorporating Twitter in the classroom, Dunlap and Lowenthal (2009) concluded that students and faculty 'were able to engage in sharing, collaboration, brainstorming, problem solving, and creating moment-to-moment experiences' (p. 47). Additionally, Twitter could develop students' fluency in written (writing and reading) and oral (speaking and listening) skills, allow them to focus on what they want to say better within 140 characters, lead them to more interactive and quick discussions, and enhance their metacognition (Dervin, 2009). These assertions are similar to the findings of Mork (2009) and Harmandaoglu (2012) who identified some advantages for using Twitter in education as follows: 
1. It allows teachers to send reminders to students about assignments, tests, etc.

2. It changes classroom dynamics.

3. It encourages collaboration and feedback. Teachers can post a link or a question for students to respond to together using Twitter's system of responding to a single person.

4. It encourages concise writing and focuses the attention with its 140 characters. Teachers can use Twitter to force students to be concise and to get right to the point.

5. It keeps track of a conversation students carry on a particular topic.

Although Twitter has plenty of advantages as a teaching and learning tool, it also poses some disadvantages. Tweeting could be too distracting, time-consuming, and addictive for some students. Tweeting could also lead to spreading rumors and spams as well as violating student's privacy. To avoid its limitation of 140 characters, some students may ignore some grammatical rules and use incorrect grammar (Grosseck and Holotescu, 2008).

\subsection{Instagram as an ESL/EFL Tool}

Launched in 2010 as a photo-sharing social networking service, Instagram has now become the eighth mostly visited SNS worldwide (eBizMBA, 2016), and has gained immense popularity and attention from all types of users and industries (Lee, Lee, Moon, and Sung, 2015). Instagram allows users to perform a number of functions: create accounts, post content (pictures or 15-second videos), apply filters, add captions, tag users, add locations, add hashtags, like content, add comments, browse and follow other accounts, check a feed generated by followed accounts, and explore (search for) hashtags/users (Al-Ali, 2014). Not only could Instagram develop descriptive language, but it also could develop cultural awareness and competence (Lomicka and Lord, 2009). With the power of pictures, Instagram has also been associated with the development of linguistic, spatial, mathematical, interpersonal, intrapersonal intelligences (Phillips, 2013).

Although very few research studies have been conducted to utilize Instagram in educational settings, Kelly (2015) claimed that Instagram is an ideal learning environment for ESL/EFL learners because it can provide them with the opportunities to read and write through photo descriptions, comments, and direct messages as well as develop their vocabulary range and grammatical accuracy. These findings are similar to what was reported by Al-Ali (2014) who argued that Instagram offers many advantages as follows:

1. It provides contextualized visual data that can be effectively used in ESL/EFL classrooms.

2. It creates a socially connected community of ESL/EFL learners.

3. It is commonly used and largely accepted by young learners.

4. It is easily accessed through a mobile app.

5. It promotes student-teacher and student-student interactions.

As with other SNS, Instagram has also some limitations. Privacy is one of the main issues that is often raised when using Instagram in educational settings. Some students may reveal some private pictures or images that may discriminate against age, gender, race, disability, and religious orientation.

\section{Conclusion}

Incorporating SNS into ESL/EFL teaching and learning has tremendous benefits for both instructors and students. Instructors can develop pedagogically sound activities for their students to foster linguistic and cultural development in their classes and students can engage in and with L2 in ways that were not possible before (Lomicka and Lord, 2009). Additionally, when incorporating SNS into the ESL/EFL classroom settings, instructors need to be aware of their limitations and take measures to develop their students' learning experiences. Certain groups of learners, such as those from low socio-economic backgrounds and those living in remote areas, face some challenges when integrating SNS in their language learning. Other challenges and limitations that should be carefully and thoroughly addressed and considered include the management of personal information and privacy, the risk of predation and cyberbullying, the laws of intellectual copyright, and safety and wellbeing (Collin, Rahilly, Richardson, and Third, 2011).However, it is obvious that SNS present both a major change and challenge to the traditional classroom settings. SNS require a significant shift in the teaching approaches that challenge the traditional instructional methods. SNS provide learners with the opportunity to create their own digital learning materials, personal learning environments, and social networks; and therefore, they require an institutional environment that encourages and rewards exploration, communication, critical thinking, and risk taking. It is also critical that educational institutions have their own policies and processes in place that encourage dynamic transition and change from traditional to SNS-assisted language learning environments, innovative uses of SNS inside and outside the classroom settings, and monitoring and evaluation of the ESL/EFL teachers as well as students while integrating SNS into their teaching and learning practices.

Institutions should ensure that SNS tools are used in educationally meaningful ways. (Bates, 2011). Not only should the institutional and national polices be considered and addressed when integrating SNS into the ESL/EFL classroom settings, but also the cultural values and social norms of all the SNS stakeholders should be taken into account. Cultural and social factors and obstacles should be considered and addressed to overcome the barriers that prevent instructors from adopting SNS in their teaching practices. Institutions should provide instructors with training and professional development in order to promote their SNS competence and facilitate their SNS adoption in their teaching practices. The use of SNS should be embedded in pre-service as well as in-service teaching training courses. As a top-down approach, schools and institutions need to support teachers and educators by providing them with technical and 
pedagogical guidance. As a bottom-up approach, identifying creative teaching and learning practices encourages ESL/EFL teachers to reconsider their teaching methods (Manca and Ranieri, 2015). Institutions should also explain at policy level their expectations towards the adoption of SNS for teaching in order to allocate actual time and infrastructure required to implement SNS in the ESL/EFL teaching and learning settings (Manca and Ranieri, 2015).

More targeted research needs to be undertaken to maximize the benefits of SNS and identify best practices. Quantitative and qualitative research is also recommended to understand who is and who is not using SNS and why (Boyd and Ellison, 2007). Also, more studies are needed to explore and compare between the teachers' and students' attitudes towards using SNS in ESL/EFL contexts. Additional research might be conducted on student's learning styles in relation to their willingness to use SNS for language learning. Future research should also explore how learners in primary and secondary educational settings as well as in more informal learning contexts are using SNS.

\section{References}

Al-Ali, S. (2014). Embracing the Selfie Craze: Exploring the Possible Use of Instagram as a Language mLearning Tool. Issues and Trends in Educational Technology, 2(2): 1-16. https://doi.org/10.2458/azu_itet_v2i2_ai-ali

Alm, A. (2006). CALL for autonomy, competence, and relatedness: Motivating language learning environments in Web 2.0. The JALT CALL Journal, 2(3), 29-38. Retrieved from http://journal.jaltcall.org/articles/2_3_Alm.pdf

Bates, T. (2011) Understanding web 2.0 and its implications for education in Lee, M. and McCoughlin, C. (Eds.) Web 2.0-Based E-Learning: Applying Social Informatics for Tertiary Teaching. Hershey PA: Information Science Reference.

Blattner, G., and Fiori, M. (2009). Facebook in the language classroom: Promises and possibilities. International Journal of Instructional Technology, 6(1), 17-28. Retrieved from http://www.itdl.org/Journal/jan_09/article02.htm

Borau, K., Ullrich, C., Feng, J., and Shen, R. (2009). Microblogging for language learning: Using Twitter to train communicative and cultural competence. Advances in web learning-ICWL, Lecture Notes in Computer Science. 5686, 78-87. http://dx.doi.org/10.1007/978-3-642-03426-8_10

Boyd, D.M., and Ellison, N.B. (2007). Social Network Sites: Definition, History, and Scholarship. Journal of computermediated communication, 13 (1): 210-230. http://doi.org/10.1111/j.1083-6101.2007.00393.x

Burke, S., Snyder, S., and Rager, R.C. (2009). An Assessment of faculty usage of YouTube as a teaching resource. The Internet Journal of Allied Health Sciences and Practice, 7(1).

Canale, M., \& Swain, M. (1980). Theoretical bases of communicative approaches to second language teaching and testing. Applied Linguistics, 1, 1-47. http://doi.org/10.1093/applin/I.1.1

Carmean, C., and Haefner, J. (2002). Mind over matter: Transforming course management systems into effective learning environments. EDUCAUSE Review, 37(6), 27-37.

Carr, C.T. and Hayes, R.A. (2015). Social Media: Defining, Developing, and Divining. Atlantic Journal of Communication, 23:1, 46-65. http://doi.org/10.1080/15456870.2015.972282

Chartrand, R. (2012). Social networking for language learners: Creating meaningful output with Web 2.0 tools. Knowledge Management \& E-Learning: An International Journal, 4(1), 97-101. Retrieved from http://www.kmeljournal.org/ojs/index.php/online-publication/article/view/170/124

Chen, S., Diao, Y., and Zhang, J. (2011). Social media: Communication characteristics and application value in distance education. Second International Conference on Electrical and Control Engineering (ICECE), Yichang, China. Retrieved from

https://www.researchgate.net/publication/252053995_Social_media_Communication_characteristics_and_application_ value_in_distance_education

Clarkson, K. (2013). Usage of Social Network Sites amongst University Students. Munich, Germany: Grin Verlag.

Collin, P., Rahilly, K., Richardson, I. and Third, A. (2011) The Benefits of Social Networking Services: A literature review. Cooperative Research Centre for Young People, Technology and Wellbeing. Melbourne.

Duffy, P. (2011). Facebook or faceblock: Cautionary tales exploring the rise of social networking within tertiary education in Lee, M. and McCoughlin, C. (Eds.), Web 2.0-based E-learning: Applying social informatics for tertiary teaching. Hershey, PA: Information Science Reference.

Dunlap, J., and Lowenthal, P.R. (2009). Instructional uses of Twitter. In P. R. Lowenthal, D. Thomas, A. Thai, \& B. Yuhnke (Eds.), The CU Online Handbook: Teach Differently: Create and collaborate (pp. 46-52). Raleigh, NC: Lulu Enterprises.

Ellison, N. B. (2008). Introduction: Reshaping campus communication and community through social network sites. The ECAR Study of Undergraduate Students and Information Technology, 8, 19-32. Retrieved from https://net.educause.edu/ir/library/pdf/ers0808/rs/ers0808w.pdf

Ellison, N. B. and Boyd, D. (2013). Sociality through Social Network Sites. In Dutton, W. H. (Ed.), The Oxford Handbook of Internet Studies. Oxford: Oxford University Press, pp. 151-172. 
Fenner, A.B. (2008). Cultural awareness in the foreign language classroom. In J. Cenoz \& N. H. Hornberger (Eds.) Encyclopedia of Language and Education, (pp. 273-285). New York: Springer Science + Business Media LLC. http://dx.doi.org/10.1007/978-0-387-30424-3_155

Grosseck, G., and Holotescu, C. (2008). Can we use Twitter for educational activities? Paper presented at the 4th International Scientific Conference, eLearning and Software for Education, Bucharest, Romania.

Hanafi, H. Alberth, Wiramihardja, E., Siam, and Badara, A. (2013). International Journal of Science and Research (online), pp. 2319-7064. Retrieved from http://www.ijsr.net/archive/v4i2/SUB15989.pdf

Harmandaoglu, E. (2012). The Use of Twitter in Language Learning and Teaching. International Conference: ICT for Language Learning, $5^{\text {th }} \quad$ edition. $\quad$ Retrieved from http://conference.pixelonline.net/ICT4LL2012/common/download/Paper_pdf/211-IBT41-FP-Harmandaoglu-ICT2012.pdf

Ho-Abdullah, I., Hashim, R. S., Jaludin, A., and Ismail, R. (2011). Enhancing opportunities for language use through web-based social networking. International Conference on Social Science and Humanity, 5, 136-139.

Howard, P. N., and Parks, M. R. (2012). Social media and political change: Capacity, constraint, and consequence. Journal of Communication, 62, 359-362. http://dx.doi.org/10.1111/j.1460-2466.2012.01626.x

Hung, H.T. and S.C. Yuen. 2010. Educational use of social networking technology in higher education, Teaching in Higher Education, 15, no. 6: 703-14.

Kachniewska, M. (2015). Gamification and Social Media as Tools for Tourism Promotion. Handbook of Research on Effective Advertising Strategies in the Social Media Age. pp. 17-51. http://dx.doi.org/10.4018/978-1-4666-8125$5 . \operatorname{ch} 002$

Kamel, S. (2016). Electronic Commerce Challenges and Opportunities in Egypt. Encyclopedia of E-Commerce Development, Implementation, and Management. pp. 1229-1240. http://dx.doi.org/10.4018/978-1-4666-9787-4.ch088

Kaplan A. M., Haenlein M. (2010). Users of the world, unite! The challenges and opportunities of social media. Business Horizons. 53 (1). p. 61. http://dx.doi.org/10.1016/j.bushor.2009.09.003

Kelly, R. (2015). An Exploration of Instagram to Develop ESL Learners' Writing Skills. Unpublished master's dissertation, Ulster University.

Kikuchi, K., and Otsuka, T. (2008). Investigating the use of social networking services in Japanese EFL classrooms. The JALT CALL Journal, 4(1), 40-52. Retrieved from http://journal.jaltcall.org/articles/4_1_Kikuchi.pdf

Lee, E., Lee, J.A., and Moon, J.H. (2015). Pictures Speak Louder than Words: Motivations for Using Instagram. Cyberpsychology, Behavior, and Social Networking, 18(9): 552-556. http://dx.doi.org/10.1089/cyber.2015.0157

Lomicka, L. \& Lord, G. (2009). The Next generation: Social networking and online collaboration in foreign language learning. San Marcos, TX: Computer-Assisted Language Instruction Consortium (CALICO).

Manca, S. and Ranieri, M. (2015). Implications of social network sites for teaching and learning. Where we are and where we want to go. Education and Information Technologies, pp. 1-18. http://dx.doi.org/10.1007/s10639-015-9429-x

Manca, S. and Ranieri, M. (2016). "Yes for sharing, no for teaching!": Social media in academic practices. The Internet and Higher Education, 29, 63-74. http://dx.doi.org/10.1016/j.iheduc.2015.12.004

Manuel, J. T. and M. P. Schunke. (2016). Meeting students where they are online, but leading them somewhere more interesting: Reflections on teaching the Facebook class. College Teaching 64, no. 3: 112-118.

Mork, C. (2009). Using Twitter in EFL Education. The JALT CALL Journal, 5(3). 41-56. Retrieved from http://journal.jaltcall.org/articles/5_3_Mork.pdf

Morris, N.O. (2011). Using Technology in the EFL Classroom in Saudi Arabia. MA TESOL Collection. Paper 511. Retrieved from http://digitalcollections.sit.edu/cgi/viewcontent.cgi?article=1514\&context=ipp_collectionSwanson, R. A., \& Holton, E. F. (1997). Human resource development research handbook: Linking research and practice. San Francisco, CA: Berrett-Koehler Publishers, Inc.

Obar, J. A., and Wildman, S. (2015). "Social media definition and the governance challenge: An introduction to the special issue". Telecommunications policy. 39 (9): 745-750.

Pauwels, A. (2011). Future directions for the learning of languages in universities: challenges and opportunities. The Language Learning Journal 39, no. 2: 247-257.

Philips, J. (2013). Using Instagram in an Educational Context. Emerging EdTech. Retrieved from http://www.emergingedtech.com/2013/02/using-instagram-in-an-educational-context

Robbins-Bell, S. (2008). Higher Education as Virtual Conversation. EDUCAUSE Review, 43(5), 24-26.

Saykili, A., and Kumtepe, E. G., (2016). Facebook's Hidden Potential: Facebook as an Educational Support Tool in Foreign Language Education. Social Media and Networking: Concepts, Methodologies, Tools, and Applications. Information Resources Management Association: USA, pp. 684-709.

The Faculty Focus. (2009). Twitter in higher education 2009: Usage habits and trends of today's college faculty. Retrieved from http://www.facultyfocus.com/free-reports/twitter-in-higher-education-usage-habits-and-trends-oftodays-college-faculty 
Thelwall. M. (2009). Social network sites: Users and uses. In: M. Zelkowitz (Ed.), Advances in Computers 76. Amsterdam: Elseveir, pp. 19-73.

The World's Most Popular Social Network Sites. (2016, October 1). Retrieved from http://www.ebizmba.com/articles/social-networking-websites

Tudini, V. (2015): Interactivity in the teaching and learning of foreign languages: what it means for resourcing and delivery of online and blended programmes. The Language Learning Journal. http://dx.doi.org/10.1080/09571736.2014.994183

Vural, O. F. (2015). Positive and negative aspects of using social networks in higher education: A focus group study. Educational Research and Reviews, 10:8, pp. 1147-1166. http://dx.doi.org/10.5897/err2015.21.3.44

Wang, S., and Vasquez, C. (2012). Web 2.0 and second language learning: What does the research tell us? The CALICO Journal, 29(3), 412-430. http://dx.doi.org/10.11139/cj.29.3.412-430

Warschauer, M. (2009). Foreword. In M. Thomas (Ed.), Handbook of research on Web 2.0 and second language learning (pp. xix-xx). Hershey, PA: Information Science Reference.

Warshchauer, M. (2006). The paradoxical future of digital learning. Learn Inq, 1, 41-49.

Watkins, J. \& Wilkins, M. (2011). Using YouTube in the EFL Classroom. Language Education in Asia, 2(1). doi:10.5746/leia/11/v2/i1/a09/watkins_wilkins

Yunus, M., Salehi, H., \& Chenzi, C. (2012). Integrating social networking tools into ESL writing classroom: Strengths and weaknesses. English Language Teaching, 5(8), 42-48. http://doi.org/10.5539/elt.v5n8p42 